gulfing a certain number of nettles, metamorphose directly into cnidocysts.

On page 275 Professor Kepner quotes Grosvenor through me, and adds "likewise no one can have witnessed the discharge of nematocysts of Microstoma when stimulated by pressure or acetic acid without looking upon them as organs of defense." Yet both Cuênot ${ }^{7}$ and I proved that the defensive value of the nettles is slight if not negligible, whereas in $1909^{8}$ I showed that under certain conditions (pressure, acetic acid) the discharge of nettles, even when enclosed in mother tissues or in eolids, may be no more the outcome of physiological stimulation than the explosion of a pistol is the result of a "stimulated" trigger.

In conclusion, Professor Kepner raises the question whether eolids have " acquired their method of dealing with nematocysts of colenterates through flatworm ancestry." To any one acquainted with the relationships, not only of molluses, but of the particular ones under discussion, this question is a bit surprising, for not only is the supposed flatworm ancestry of the mollusca exceedingly problematical, but gastropods are not primitive molluscs, nor are nudibranchs primitive gastropods. One would certainly expect indications of the "nematocyst-habit" in primitive forms if there were any reasonableness in the phylogenetic point of view as applied to this problem.

Marine Brological Laboratory, Woods Hole, Mass., June 22, 1911

\section{DOUBLE MUTANTS IN SILKWORMS}

To the Editor of Science: Referring to Professor Kellogg's interesting report on "Double Mutants in Silkworms," in ScIence of May 19, 1911, I would call attention to the fact that in his original publication the puzzling data regarding the inheritance of the white cocoon character is made clear by the assumption of two kinds of white, one dominant to color, the other reces-

'Arch. de Zool. Exp., 4e S., T. 6.

${ }^{8}$ Journal of Experimental Zoology, Vol. IV. sive to color. In some of his original data certain individuals were evidently heterozygote for these two kinds of color. The recognition of both a dominant and a recessive white will also explain some of the puzzling phenomena reported in the more recent data.

W. J. SpIllman

\section{EXPLODED THEORIES AND THEOLOGICAL PREJUDICE}

These are expressions used in Professor White's review of the new edition of "The Ice Age in North America." The exploded theories mentioned are "the Calaveras skull," "the Lansing man" and "the Nampa figurine." The error concerning the Calaveras skull figured by Whitney is freely granted in the book. But that there was a skull found as described, and other remains of man, in the auriferous gravels is still supported by a sufficient amount of convincing evidence to command attention.

As to the Nampa figurine, I am not aware that any one has brought anything but theoretical considerations to bear against the evidence originally collected by Charles Francis Adams and his associates immediately after its purported discovery; while the theoretical considerations are based, as I have shown, upon misunderstanding of the geological conditions. The cataclysm connected with the bursting of the upper barriers of Lake Bonneville, and the pouring of its waters into the Snake River valley must be reckoned with before the conditions reported at Nampa are set down as incredible.

The facts relating to the Lansing man are, I think, sufficiently set forth in the book to, at least, merit attention. If we are to accept every attempt to explode a theory as successful we shall soon come to a standstill in our discussions.

As to theological prepossessions, I only remark that it is as easy to impute antitheological prepossessions, as to suspect theological bias. In any event the facts themselves should not be overlooked. Let us have fair play.

G. Frederick Wright

OBERLIN, O., June 17, 1911 